\title{
SUMMARY OF THE PHYTOCHEMICAL RESEARCH PERFORMED TO DATE ON SIDERITIS SPECIES
}

Dragica Bojovic ${ }^{1}$, Slobodan Jankovic ${ }^{2}$, Zorica Potpara ${ }^{3}$ and Vanja Tadic ${ }^{4}$ ${ }^{1}$ Galenika Montenegro, Podgorica, Montenegro

${ }^{2}$ Pharmacology Department, Medical Faculty, University of Kragujevac, Kragujevac, Serbia

${ }^{3}$ Pharmacy Department, University of Montenegro, Podgorica, Montenegro

${ }^{4}$ Institute for Medicinal Plant Research, Dr Josif Pančić, Belgrade, Serbia

\section{PREGLED DOSADAŠNJEG FITOHEMIJSKOG ISPITIVANJA SIDERITIS VRSTA \\ Dragica Bojović ${ }^{1}$, Slobodan Janković ${ }^{2}$, Zorica Potpara ${ }^{3}$ and Vanja Tadić ${ }^{4}$ \\ ${ }^{1}$ Galenika Crna Gora, Podgorica, Crna Gora \\ Medicinski fakultet Univerziteta u Kragujevcu, Kragujevac, Serbia \\ Farmaceutski fakultet Univerziteta u Podgorici, Podgorica, Crna Gora \\ ${ }^{4}$ Institut za proučavanje lekovitog bilja "Dr Josif Pančić"}

\begin{abstract}
From a botanical perspective, the large number of species of the genus Sideritis coupled with the tendency to hybridise between the different species has prompted an accurate study designed to clarify all the controversial points in the botanical classification of this genus. The past phytochemical studies of the Sideritis species have been performed with different extracts from the aerial parts, essential oils and isolated compounds such as diterpenoids, flavonoids or phenylpropanoid glycosides. These investigations have justified the traditional uses for these plants and provided direction for new pharmacological research.

In recent years, other compounds such as iridoids, coumarins, lignans and phenylpropanoid glycosides have also been isolated and identified. The results have shown that essential oils act as good antimicrobial agents against both Gram-positive and Gram-negative bacteria and against the Candida albicans fungus. Diterpenoids have shown antimicrobial, anti-inflammatory and antifeedant activity, and flavonoids are active as anti-ulcerous, anti-inflammatory and antioxidant agents. Future research should focus on the pharmacological activity of these isolated compounds to find new active principles and identify their mechanisms of action. In addition, it would be interesting to investigate new pharmacological activities apart from those used in traditional medicine; recent studies have shown that diterpenes and some diterpene derivatives act as effective anti-HIV and antiproliferative agents.
\end{abstract}

Keywords: Sideritis genus, traditional use, essential oils, flavonoids, antimicrobial, anti-inflammatory activity

\section{SAŽETAK}

Veliki broj vrsta u okviru roda Sideritis, njihova izražena tendencija međusobnog ukrštanja razlog je sprovođenja obimnog istraživanja u cilju razjašnjavanja kontraverznih cinjenica vezanih za botaničku klasifikaciju ovog roda. Fitohemijske studije Sideritisvrstaobuhvatajuizučavanjarazličitih ekstrakata nadzemnih delova, etarskog ulja i izolovanih jedinjenja kao što su diterpenoidi, flavonoidi ilifenilpropanoidni glikozidi, kao jedinjenja nosioci aktivnosti. Ova istraživanja omogućavaju da se sprovođenjem farmakološki osmišljenih eksperimenata opravda tradicionalna primena ovih biljaka, kao i da se opravda eventualna upotreba ovih biljaka i njihovih ekstrakata u tretmanu nekih oboljenja za koje tradicionalno nije poznata upotreba biljaka ovog roda.

U poslednjih nekoliko godina, brojna u okviru sprovedenih iscrpnih istraživanja, jedinjenja kao što su iridoidi, kumarini, lignani, kao i fenilpropanoidni glikozidi izolovani su $i$ identifikovani u ekstraktima ovih biljaka. Rezultati su pokazali da eterska ulja deluju kao dobri antimikrobni agensi i da deluju na gram pozitivne i gram negativne bakterije i glivice Candida albicans . Diterpenoidi su pokazali antimikrobno, antiinflamatorno delovanje, a doprinose i odbrani biljaka od biljojeda. Flavonoidi deluju kao anti-ulcerozni, antiinflamatorni i antioksidativni agensi. Buduća istraživanja trebalo bi da buduusmerena na ispitivanja farmakoloških aktivnosti izolovanih jedinjenja, $u$ cilju pronalaženja novih aktivnih principa i objašnjavanja mehanizma njihovog delovanja. Pored toga, istraživanja ne bi trebalo ograničiti samo na potvrdu tradicionalne upotrebe biljaka roda Sideritis, već bi bilo zanimljivo istražitimogućnost njihove upotrebe za nova indikaciona područja. Nedavne studije su pokazale da diterpeni $i$ neki diterpenski derivata pokazuju anti HIV delovanje, a poseduju i antiproliferativni efekat.

Ključne reči: Rod Sideritis, tradicionalna primena, eterska ulja, flavonoidi, antimikrobna, antiinflamatorna aktivnost

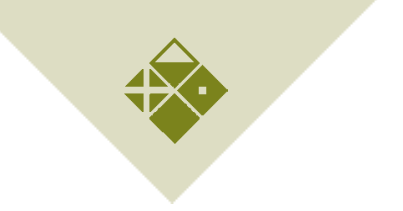




\section{INTRODUCTION}

The genus Sideritis (Lamiaceae) comprises more than 150 perennial and annual vegetal species widely distributed in the Mediterranean area, together with the Canary and Madeira islands. It is a controversial botanic genus with a complex taxonomical classification due to the high number of hybridisations that occur between species; their study requires substantial and deep research experience.

The results of numerous preliminary investigations of plants belonging to the genus Sideritis L. revealed plant-derived substances of particular pharmacological and nutritional interest. So far, a wide variety of biological activities of the Sideritis species have been reported: anti-inflammatory, anti-ulcer, analgesic, antimicrobial and antifungal (1-5), antifeedant (6), anticataract (7), immunomodulating (8) macrophage NOS-2-expression inhibiting (9) and hypoglycaemic (4). Recently, aldose reductase-inhibiting activity (12) and antiproliferative, anticholinesterase and selective oestrogen receptor modulator-like effects have been reported (11-13). The previous studies of the Sideritis species reported the presence of flavonoid aglycones and glycosides, phenolic acids, di- and triterpenoids, fatty acids, coumarins and iridoid glycosides (2, 10, 12, 14-28). Most of the studies on the Sideritis species attributed the previously cited biological activities mainly to phenolic compounds. Recently, several articles have been published describing the connection between the phenolic constituents and pharmacological activity in various Sideritis species (10, 14). Rios et al. (19) reported that flavonoids were reducing agents able to interact with free radical species (relevant to the autoxidation mechanism) and could prevent the generation of inflammatory mediators. The composition of the various Sideritis species essential oils has also been studied exhaustively $(1,20)$.

The genus Sideritis is represented in Serbia by one species only, S. montana L. (21), but because of its prooxidant properties, this plant has not been used in traditional medicine (22). S. scardica Griseb. (ironwort, mountain tea) is a plant endemic to the Balkan Peninsula, belonging to the Empedoclia section. The aerial parts of "mountain tea" are traditionally known for their anti-inflammatory, antimicrobial, antibacterial, antirheumatic and gastroprotective properties. S. scardica is used as a loosening agent in bronchitis and bronchial asthma and against the common cold and lung emphysema, as well as widely used in the treatment of inflammation, gastrointestinal disorders and coughs and as an active constituent of dietary supplements for the prevention of anaemia (23). All biological activities previously cited in the literature have been mainly attributed to the phenolic content of this plant (15).

The goal of this review is to provide a comprehensive overview of the botanical, phytochemical and pharmacological aspects of the genus Sideritis.

\section{BOTANICAL ASPECTS}

Sideritis L. (Lamiaceae) includes approximately 150 species of annual and perennial plants, distributed mainly in the Mediterranean region and in the moderate zones of Asia. The Sideritis L. genus belongs to the family of Lamiaceae Lindl. (Labiatae Juss.), which is one of the most common and diverse plant families of the world. The genus of the Lamiaceae families exists in different altitudes and habitats, ranging from the North Pole to the Himalayas and from Northeast Asia to Hawaii, Australia, Africa and America. However, its main habitat is the Mediterranean area. The taxonomy of the genus Sideritis is rather complex because of interspecies hybridisation, and therefore, it has not been satisfactorily resolved. Based on pollen features, Heywood has divided the Labiatae into two subfamilies, Lamioideae and Nepetoideae. Plants from the subfamily Lamioideae are characterised by a low concentration of essential oils, a lack of rosmarinic acid and the presence of iridoid glycosides; Nepetoideae plants are rich in essential oils, contain rosmarinic acid in various percentages and lack iridoids.

The position of the genus Sideritis is illustrated in Figure 1. This genus is divided into two subgenera, Sideritis and Marrubiastrum, formed by the European and Macaronesian species, respectively. The subgenus Marrubiastrum (Lamioideae: Lamiaceae) represents one of the most species-rich Macaronesian endemics, containing 24 (23 extant) perennial species distributed among the 10 islands of the Madeiran and Canary Island archipelagos. These plants display a wide range of morphological diversity and are found in all ecological zones in the islands. Growth forms include suffrutescent perennials, chasmophytic (cliffdwelling) rosette plants, and large arborescent shrubs. The Macaronesian floristic region comprises the five Atlantic Ocean archipelagos of the Azores, Madeira, Selvagen, Canary, and Cape Verde Islands and is situated between $15^{\circ}$ and $40^{\circ}$ north latitude. While some of the Macaronesian islands are comparable to their Pacific counterparts in their extreme isolation, others are much closer to continental source areas, with only $100 \mathrm{~km}$ separating the island of Fuerteventura from mainland Africa. The second, much larger subgenus, Sideritis, contains approximately 125 species of both annuals and perennials, most of which are suffrutescent but none truly woody, with a centre of distribution in Mediterranean Europe and northern Africa. It comprises four sections, two of which, Hesiodia and Burgsdorffia, are small groups containing only annual species distributed widely throughout the Mediterranean and Central Asia. The remaining two continental sections, Sideritis and Empedoclia, contain suffrutescent perennials with centres of diversity in the western Mediterranean area (especially the Iberian Peninsula) and the eastern Mediterranean (Balkans, Turkey, Syria), respectively $(24,25)$. The continental taxa have a Mediterranean centre of distribution, although a few species 


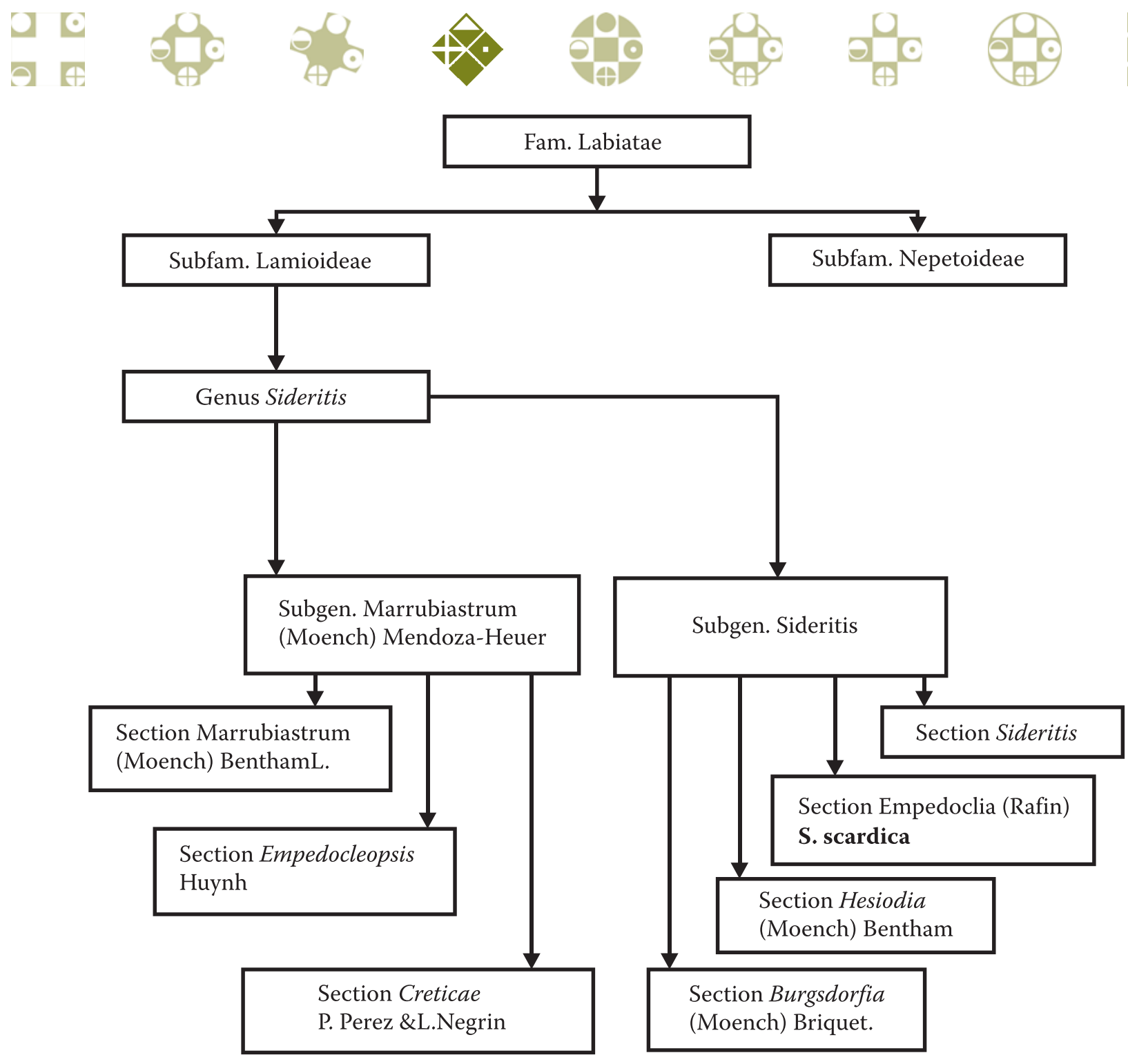

Figure 1. The "botanical tree" of the Sideritis genus and the position of S. scardica

of Sideritis are also found in the Balkans, Eurasia, and the Mideast. The section Sideritis contains taxa from the western Mediterranean regions of southern Europe and northern Africa. The species forming the section Empedoclia are found in the countries of the eastern Mediterranean (Greece, Turkey) and the Mideast (Israel, Lebanon, Palestine, Iraq, Syria). The morphological characteristics that distinguish the two sections include dentate/spinose bracts and tetracolpate pollen in the section Sideritis vs. entire bracts and sixpantocolpate pollen in the section Empedoclia.

In addition, it is important to point out that the Sideritis genus contains a large number of endemic species: 46 species, 12 subspecies and two varieties grow in Turkey, with 36 species, 10 subspecies and two varieties of them being endemic (77\% endemism ratio). Twenty-five Sideritis species grow in Morocco, 16 of which are endemic. The Iberian Peninsula and the Baleares Islands contain 49 Sideritis species, of which 36 are endemic; in the Canary Islands, this genus is represented by 19 endemic species.

\section{TRADITIONAL USES}

The aerial parts of plants from the genus Sideritis are widely used as a popular decoction or infusion, orally or topically administered. Most of the medicinal uses of Sideritis spp. are limited to folk medicine, although it is worth noting the increasingly frequent presence of Sideritis spp. in the herbal remedies market and the increasing number of prescriptions that contain the Sideritis species. In Mediterranean folk medicine, aqueous preparations of plants of this genus are considered as antioxidant, antiinflammatory, anti-ulcerative, antimicrobial, vulnerary, antispasmodic, anticonvulsant, analgesic and carminative agents (26). In Spanish folk medicine, some Sideritis species are known as "rabo de gato" or "zahare ña". This last name seems to be the oldest common way to name some Sideritis species, such as S. hirsuta or S. arborescens. The different plant parts have different modes of use; the infusion of the aerial parts has been used for its gastroprotective properties, whereas the decoction of the leaves 


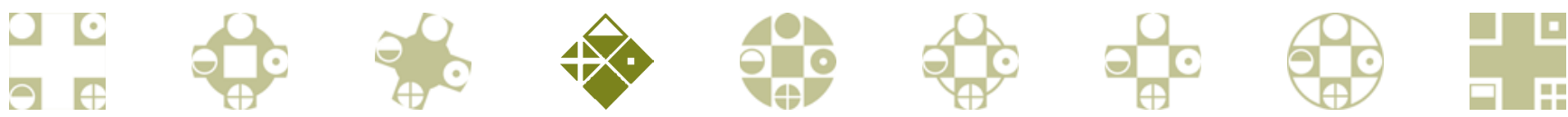

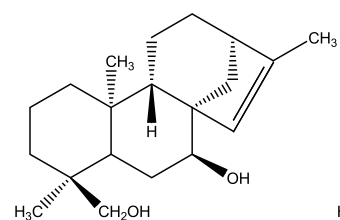

1, Sideridiol

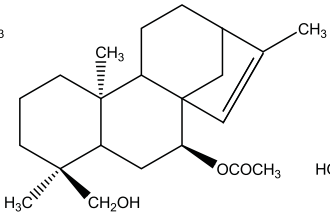

2, Siderol

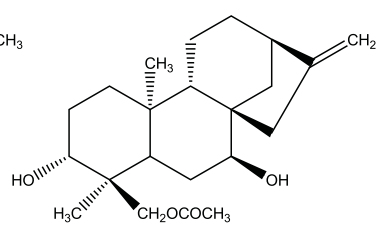

3 , Linearo

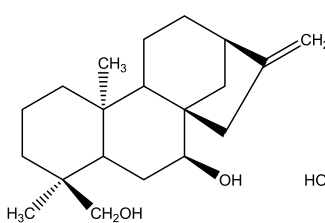

conchitriol, 11

4, Epicandicandiol

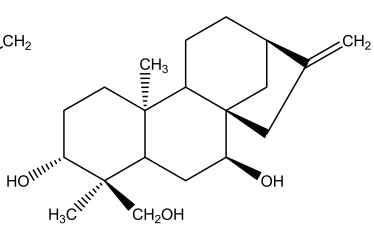

5, Foliol

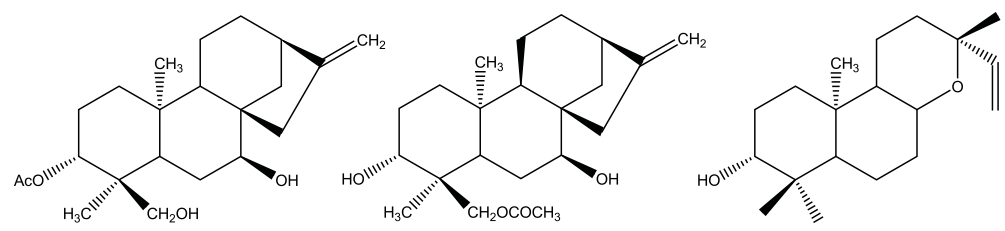

6, Sidol

7, Isolinearol

8, Ribenol

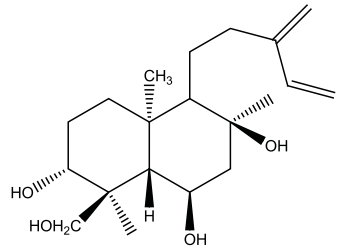

9, Andalusol

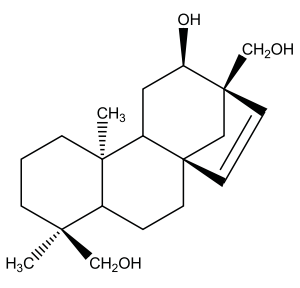

10, Tobarrol

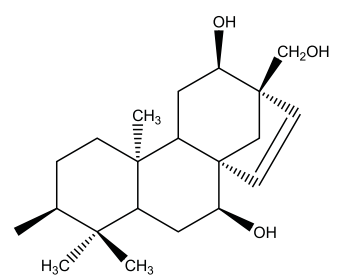

11, Conchitriol

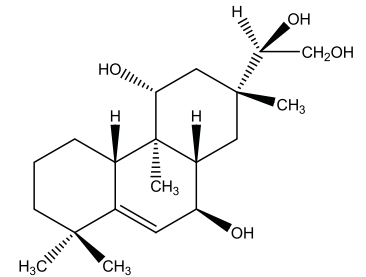

12, Lagascitriol

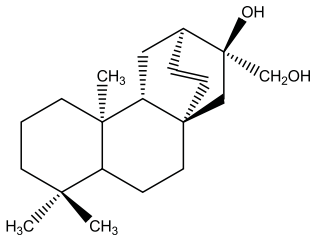

13, Serradiol<smiles>COc1ccc(-c2cc(=O)c3c(O)c(OC)c(OC)cc3o2)cc1</smiles>

14, Cirsimaritin

15, Salvigenin

16, Nepetin

17, Sideritoflavone<smiles>COc1ccc(-c2cc(=O)c3c(O)c(OC)c(OC)c(OC)c3o2)cc1</smiles>

18, Xanthomicrol

19, Gardenin-B

20, Hypolaetin<smiles>O=c1cc(-c2ccc(O)cc2)oc2c(O)c(O)cc(O)c12</smiles>

21, Isoscutellarein<smiles>COc1cc(-c2cc(=O)c3c(O)cc(O)cc3o2)ccc1O</smiles>

25, Chryseriol

Figure 2. The structures of compounds isolated from the Sideritis species 


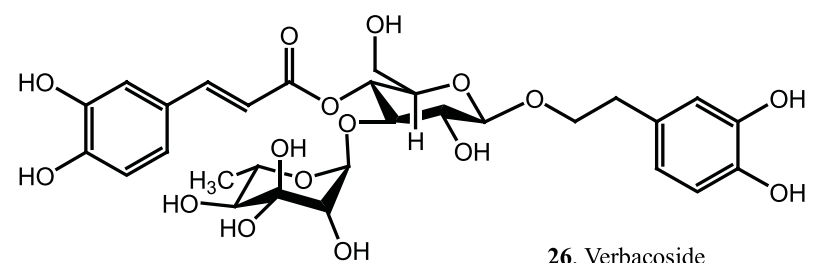

26, Verbacoside
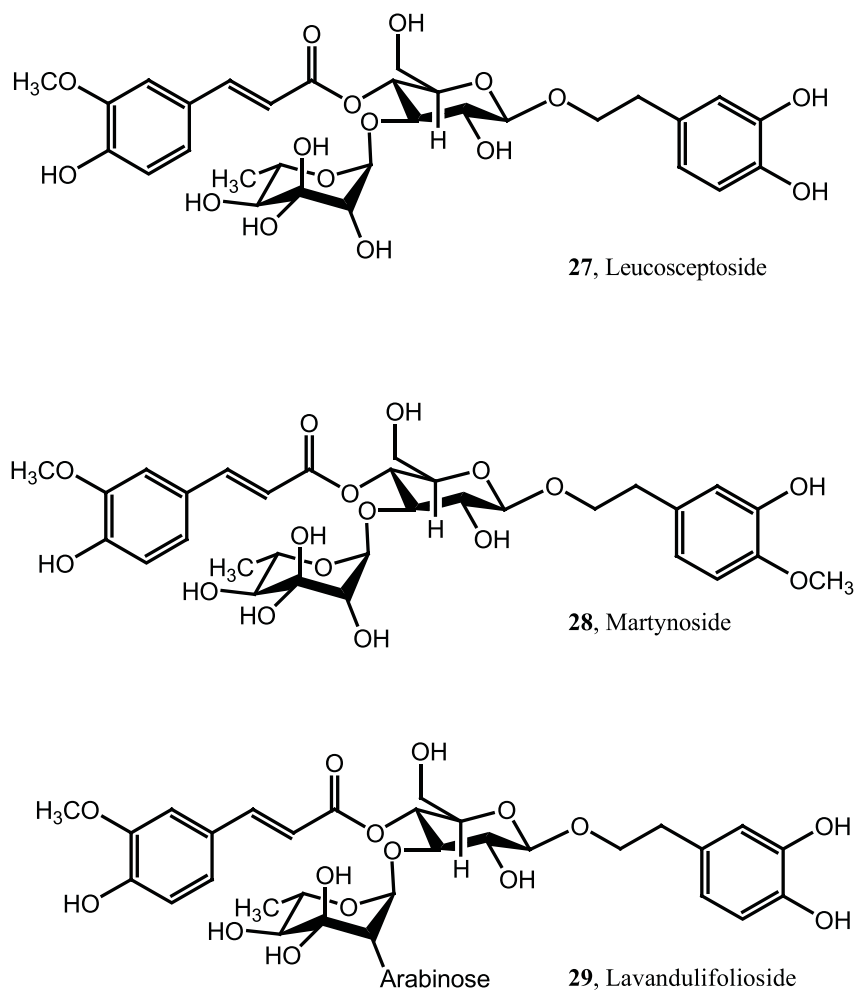

Figure 2. The structures of compounds isolated from the Sideritis species

has been employed as an anti-inflammatory and antirheumatic preparation. Moreover, the water extract of the stalks has been employed externally for disinfecting and healing wounds and burns. In Turkey, where the Sideritis species are known as "dag cayi, yayla cayi", and in Greece, the aerial parts of these plants are widely used to prepare herbal remedies and traditional teas against gastrointestinal disorders such as stomach ache, indigestion and flatulence, to alleviate the symptoms of common colds including fever, flu, sore throat, and bronchitis and a tonic and diuretic remedy. The Sideritis teas are named in a variety of ways, but they are commonly known as "mountain tea" because some species grow in the high mountain areas.

The plants of this genus are widely used in traditional medicine in Greece and Europe due to their anti-inflammatory, anti-rheumatic, anti-ulcer, digestive and antimicrobial properties, which are attributed to their phenolic and terpenoid content $(1,2,27)$. Differences in uses have been observed among the Sideritis spp. and the regions where they grow, depending on the plants' properties. Some of them are widely used in folk medicine in the Balkan countries as herbal teas for the treatment of inflammations, coughs and gastrointesti- nal disorders. In the Taurus Mountains of Turkey, a poultice prepared with boiled leaves of S. psidica, barley flour, grated onion and pine tar is applied on the abdomen as a plaster to treat abdominal pain. Furthermore, in Turkey, S. syriaca is used as a diuretic agent and to relieve coughs. An infusion prepared from the leaves and flowers of S. leptoclada is used because of its expectorant effect and to fight the common cold in the inner west of Anatolia (Turkey) (28). The endemic species $S$. trojana is one of the most demanded and consumed medicinal plants in bazaars by Turkmens and villagers who live in the sacred mountain called Mount Ida, "the mountain of the Goddess", for the treatment of throat, peptic and chest illnesses (29). In Madeira and the Porto Santo Islands, an infusion of S. candicans ("herva branca" or "selvageira") is taken to treat bronchitis and intestinal diseases. An ethnopharmacological study of the plants growing in the Alto Tirreno Cosentino area, in the Calabria region (Southern Italy), revealed that the native people use S. syriaca leaves to stop the bleeding from a cut. In Bulgaria, the infusion of the aerial parts of $S$. scardica is employed as an expectorant for the treatment of pulmonary emphysema and angina pectoris (30). Infusions and decoctions of the leaves and flowers of S. congesta, S. libanotica and S. psidica are very popular for treating coughs, hypertension and the "worm in the eyes" syndrome (it is traditionally believed that pains in the eyes are caused by worms with black heads). In the region of Nijar-Cabo de Gata, located in southeastern Spain, S. granatensis infusions are used effectively against lower back pain and eye infections and as appetite stimulants. Moreover, a mix of S. granatensis and thyme infusion with an added tablespoon of oil is employed as a remedy for hepatic affections. To relieve the cramping that occurs commonly during menstruation, infusions or decoctions from the aerial parts of $S$. foetens, prepared alone or mixed with S. angustifolia, are traditionally used in Spain. And infusions from the species $S$. tragoriganum, one of the best-known medicinal plants found in Valencia-Alicante, Spain, are an effective treatment for healing wounds, digestive disorders and urinary tract infections as well as for making gargles and for ocular and dermical washes.

Many species of the genus growing in the western Mediterranean region, especially in Spain and Portugal, have long been studied to determine their chemical constituents, and the phytochemical data have been successfully used in chemotaxonomic studies. Although Turkey is the second largest source of the genus Sideritis, except for reports on essential oils, phytochemical information on the genus is still scant $(31,32)$.

\section{PHYTOCHEMICAL AND PHARMACOLOGICAL INVESTIGATION}

Many chemical constituents have been identified in the Sideritis genus, such as terpenes, flavonoids, essential oils, iridoids, coumarins, lignans and sterols. The activity of these plants is mainly due to their flavonoid and terpenoid contents. 
The Sideritis species are known for the presence of diterpenes of a remarkable structural variability. Sesquiterpenes and triterpenes are not common. S. italica was the first genus investigated in the context of the presence of diterpenes; the diterpenoids, sideridiol (1) and siderol (2), were the first isolated, and their structures were elucidated. The diterpenoids analysis led to the conclusion that kaurene diterpenes were exclusively present in the species occurring in the eastern and central Mediterranean area (Turkey, Greece and Italy). Not only kaurenes but also isokaurene derivatives are found in Sideritis species from Greece, whereas the species from Spain and the Canary Islands are rich in kaurenes, but isokaurenes are less common. Species growing in the western Mediterranean area and Macaronesic regions contain diterpenes with different carbon skeletons (ent-kaurane, labdane, atisene, pimarane, beyerane, trachilobane and rosane). In the literature, it is reported that the ent-kaurene compounds of S. siplylea Boiss include siderol (2), linearol (3), epicandicandiol (4) and foliol (5) in addition to other compounds. The most common kaurene diterpene derivatives found in the Sideritis species are foliol (5), sidol (6), linearol, sideridiol, and isolinearol (7). Aside from the compounds previously mentioned, the most common are labdane (ribenol, 8, andalusol, 9), beyerane (tobarrol, 10 and conchitriol, 11), rosane (lagascatriol, 12) and atisane (serradiol, 13). The ent-kaurene diterpenes have been studied in microbiological transformation reactions, and a hydroxyl group appears to exert an inhibitory effect on transformations involving oxidation at C-19 (12). Tobarrol is present only in traces in some of the species studied. As expected, there were only traces of terpenoids in the methanol extract. In general, the diterpenoid content was higher in the hexane extracts than in the methanol extracts, andalusol having a higher proportion in both the hexane and the methanol extracts. The previously described anti-inflammatory activity of andalusol justifies the popular use of these species, especially S. pusilla and S. leucantha ssp. incana var. meridionalis, as antiinflammatory agents. The diterpenoids serve as chemotaxonomic markers (33).

Squalene, the acyclic precursor of the triterpenes and sterols, has been identified in S. argosphacelus var. spicata, S. discolor and S. lotsyi var. mascaensis. The triterpene derived from this, rhoiptelenone, was confirmed to be present in S. macrostachya. The triterpene rhoiptelenol has been isolated from S. candicans var. eriocephala, S. lotsyi, S. discolor, S. lotsyi var. mascaensis, S. tenoi and $S$. soluta. A mixture of $\alpha$ - and $\beta$-amyrin has been found in S. argosphacelus var. spicata, S. discolor, S. kuegleriana, S. lotsyi var. mascaensis and S. tenoi. The corresponding C- 28 acids, ursolic and oleanolic acids, have been isolated from S. discolor, S. candicans var. eriocephala, S. lotsyi var. mascaensis and S. soluta, and their acetates have been isolated from S. kuegleriana (25). Other pentacyclic triterpenes, erythrodiol and lupeol, have been obtained from $S$. discolor and S. argosphacelus var. spicata, respectively.
The genus Sideritis is a rich source of flavonoids. A correlation between the flavonoid type and the geographical distribution of Sideritis species has been established: 5,6,7-trioxygenated flavones (cirsimaritin, 14, salvigenin, 15 or nepetin, 16) are predominant in Macaronesian species, whereas the presence of 5,6,7,8-tetraoxygenated flavones (sideritoflavone, 17, xanthomicrol, 18 or gardenin-B, 19) is higher in Mediterranean species. The distribution of the flavone glycosides in the genus Sideritis is of interest from a taxonomic viewpoint. In particular, 8-OH-flavone glycosides are characteristic of some sections of Sideritis. The 7-allosylglycosides of hypolaetin (20), isoscutellarein (21), and 3'-hydroxy- 4'-O-methylisoscutellarein (22) were also reported from different Sideritis species, such as S. hypsophila, S. javalambrensis and S. mugronensis. In contrast to the sections of Empedocleopsis and Creticae, the section Marrubiastrum was reported as one of the richest Sideritis species in 8-OH-flavone glycosides. Among the Ibero-North African Sideritis species, the species of the section Sideritis (Eusideritis Bentham) were also characterised by the accumulation of the 7-glycosides of 8-OH-flavones (isoscutellarein, hypolaetin and their methyl ethers). Moreover, the presence of 6-OH-flavone and 8-OH-flavone 7-glycosides is also a characteristic feature of the Lamiaceae, Scrophulariaceae and chemically related families. It was observed that $S$. brevibracteata produces a good anti-inflammatory, antinociceptive, antioxidant and AR inhibitory herbal tea, as among the 17 species (18 taxa) of Sideritis investigated, this species was found to be the richest in 8-OH-flavone glycoside content $(10,16)$. S. foetens, S. luteola, S. leucanthu var. incana represent a group of species with a higher content of polar flavonoids, such as isoscutelarin-7-glucoside and hypolaetin-8-glucoside, which are well documented for their anti-inflammatory and anti-ulcer activity, and luteoline (23), which shows vasodilatory activity (34). Furthermore, the investigation of the Macedonian Sideritis species (S. scardica, S. raeseri) illustrated the presence of a complex profile of hydroxycinnamic acids, phenylethanoid glycosides and both acetylated and nonacetylated flavonoid 7-O-glycosides. Two types of flavones, 8-OH (hypolaetin and isoscutellarein and their methoxy derivatives) and 5,7-OH (apigenin and luteolin), have been confirmed. All the flavonoid glycosides detected were 7-O-allosyl-(1,2)-glucoside derivatives, 5,8-dihydroxyflavones with a different substitution in the B-ring. Differences in the phenolic profile of hydroxycinnamic acid and flavonoid 7-O-glycosides were found between S. scardi$c a$ and S. raeseri. Feruloylquinic acid was detected only in the methanol extract of Sideritis raeseri (wild growing). Flavonoid 7-O-diglycosides were not detected in the methanol extract of Sideritis scardica (wild growing ) (15). The identification of the flavonoids in wild-growing populations of S. scardica and S. raeseri in this central Balkan region and the presence of two types of flavones, $8-\mathrm{OH}$ (hypolaetin and isoscutellarein and their methoxy derivatives) and 5,7-OH (apigenin, 24, and chryseriol, 25), have been confirmed, and the possibility of distinguishing between the two studied species (S. scardica and S. raeseri) has been suggested (27). 
Many studies have been performed on the chemical composition of essential oil from the Sideritis species. Although the Lamiaceae family is well known for its essential oil content, the Sideritis species cannot be considered rich in essential oil. But the correlation between the oil yield and the main group of constituents has been established - the higher the essential oil yield, the higher the monoterpene hydrocarbon content. The composition of the essential oils of several species of Sideritis was investigated by gas chromatographymass spectrometry (GC-MS) and gas chromatography (GC) techniques. A large number of studies about the essential oil compositions in Sideritis now explain the polymorphism among the populations and the existence of new species, chemical varieties and hybrids. Several Sideritis essential oils are characterised by high contents of monoterpene hydrocarbons with $\alpha$-pinene, $\beta$-pinene, sabinene, myrcene or limonene as the main compounds. An important number of sesquiterpene hydrocarbons, particularly $\delta$-cadinene and $\beta$-caryophyllene, are normally also found. Other essential oils are rich in oxygenated sesquiterpenes, such as $\alpha$-cadinol, bisabolol or muurol-5-en-4 $\beta$-ol, as the main compounds, and finally, diterpene compounds have also been found in Sideritis essential oils. The presence of diterpenes as volatile compounds has been described in other genera, such as Cistus, Wollemia, Juniperus and Helichrysum, characterised by the same feature that occurs in Sideritis, with a large number of these compounds present in the aerial part extracts. Their existence is interesting because it offers another tool for a better understanding of the chemotaxonomic relationship among Sideritis species. Analysis based on the presence or absence of volatile diterpene compounds may be promising as chemotaxonomically important for the whole genus. Turkey's endemic species S. bilgerana, S. ozturkii and S. cilicica were rich in the monoterpene hydrocarbons $\alpha$ - and $\beta$-pinene. S. cilicica has been shown to have relatively high content of $\beta$-phellandrene (35). In the group of Sideritis species rich in sesquiterpenes, the main constituents have been found to be $\beta$-caryophyllene, D-germacrene and calamene (S. curvidens, S. montana). Oxygenated derivatives are not common as main constituents in the Sideritis species. Oxygenated monoterpenes, along with thymol, are characteristic constituents in S. romana. Oxygenated sesquiterpenes predominate in the essential oils of $S$. phlomoides and S. taurica. The main constituents of $S$. congesta and $S$. argyrea essential oils are $\alpha$ - and $\beta$-pinene, while limonene is the major constituent of $S$. perfoliata essential oil. S. condensata provides an essential oil with high proportions of $\beta$-caryophyllene and $\alpha$-pinene (36). S. perfoliata and S. dichotoma essential oils are rich in diterpenes (37). Monoterpene hydrocarbons have also been reported as a main constituent in the Sideritis species growing in Greece and in some Spanish species. In the essential oil of the endemic Spanish species S. ibanyezii, sabinene and $\alpha$-pinene have been found as main compounds $(20,38)$. Because there are many reports on the chemical composition of Sideritis species, it may be useful to present Table 1, which shows both the yields and the main components, and the species are presented in alphabetical order.
Table 1. Main constituents and yields of the essential oils of Sideritis sp., as previously reported

Concerning the other constituents, the recently performed investigation confirmed that iridoids are rare compounds in these species, as are coumarins and lignans. The presence of fatty acids in the seed oil composition has been reported, assuming linoleic acid as the main fatty acid. Phenylpropanoid glycosides have been isolated from the aerial parts of several Sideritis species. Verbascoside (26), leucosceptoside (27), martynoside (28), and lavandulifolioside (29) were determined to be the most important compounds with respect to their pharmacological properties $(17,39-42)$. Verbascoside is a phenolic compound known for its antiproliferative, cytotoxic, antioxidant, and antimetastatic properties.

A variety of biological activities of Sideritis species have been reported: anti-inflammatory, anti-ulcer, analgesic, antimicrobial and antifungal, antifeedant, anticataract, immunomodulating, macrophage NOS-2-expression-inhibiting, and hypoglycaemic. Recently, aldose reductaseinhibiting activity, antiproliferative, anticholinesterase and selective oestrogen receptor modulator-like effects have been reported.

\section{Anti-inflammatory activity}

The species of the genus Sideritis are known in traditional medicine for their anti-inflammatory activity. $\mathrm{Nu}$ merous studies have validated this therapeutic indication. The diterpenoid contents in several species of Sideritis can be correlated with their anti-inflammatory properties.

Hernandez-Pérez and Rabanal (5) studied the antiinflammatory and analgesic activity of $S$. canariensis var. pannosa, and the ethanol extract and the chloroform fraction were both shown to exhibit strong anti-inflammatory and analgesic activities, possibly due to the rich diterpenoid content. The same group also investigated the effects of S. candicans Ait. var. eriocephala Webb (43). These results showed a significant anti-inflammatory activity against carrageenan-induced paw oedema and against TPA (12-O-tetradecanoylphorbol acetate)-induced ear oedema in mice after oral and topical administration, respectively. Aboutabl et al. (4) postulated that the flavonoids and terpenoids in the dichloromethane fraction of S. taurica might be the active anti-inflammatory ingredients.

The lipidic fractions of Sideritis javalambrensis hexane extract exhibit potent anti-inflammatory activity. Namely, in carrageenan-induced paw oedema, oral administration of 50 and $100 \mathrm{mg} / \mathrm{kg}$ of the lipidic fraction significantly inhibited the paw oedema formation at different times. In the same way, in TPA-induced ear oedema in mice, the same fraction suppressed ear oedema formation after topical application of $0.25,0.5$ and $1 \mathrm{mg} / \mathrm{ear}$ (35, 41 and 53\% inhibition, respectively). The lipidic fraction also reduced the histamine release from mast cells and reduced NO generation in macrophages (44). Another study of S. javalambrensis extracts revealed that the hexane and methanol extracts possessed the highest anti-inflammatory activ- 


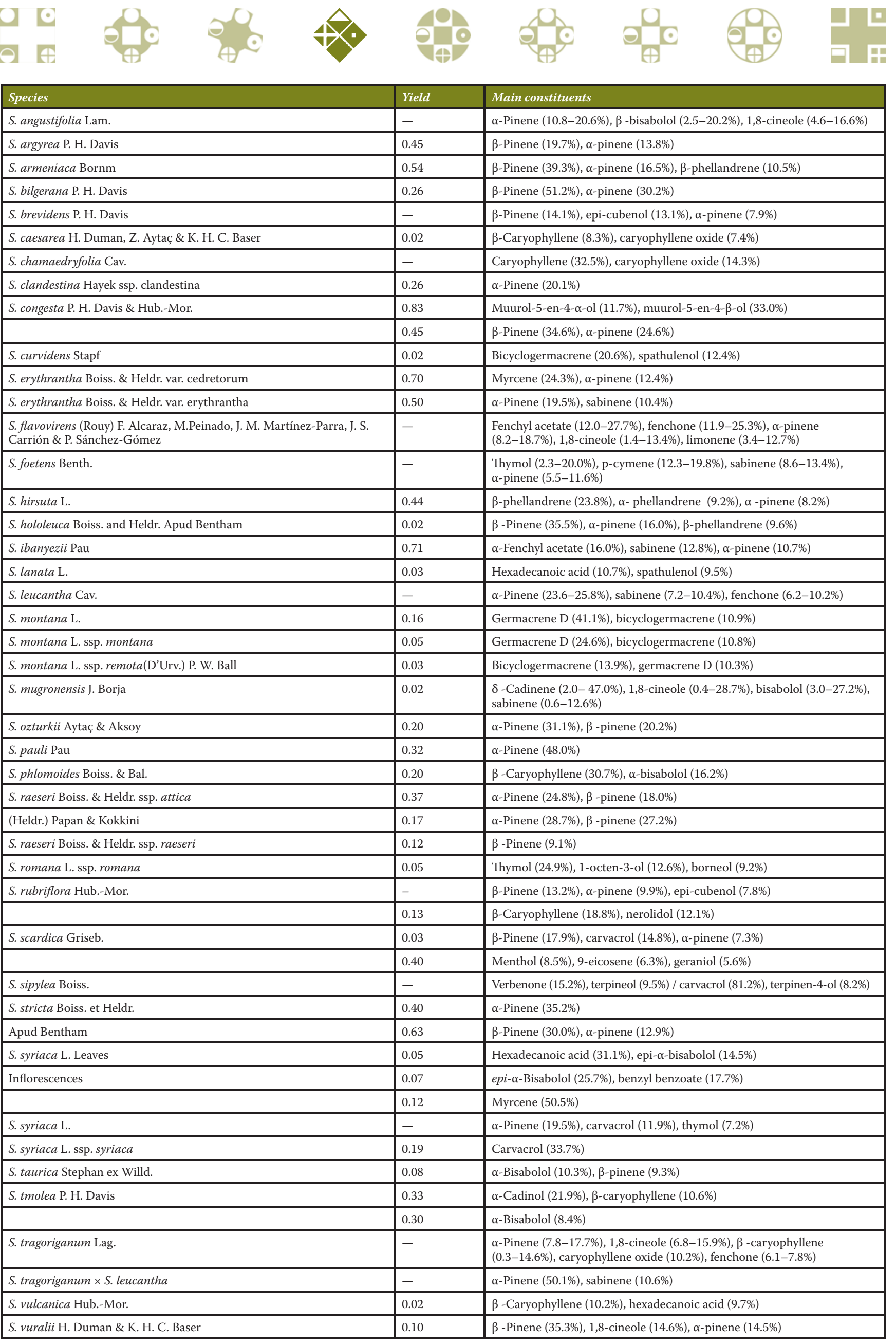


ity against adjuvant-carrageenan-induced inflammation in the chronic stage, and no effect was observed in the acute phase (9). The hexane extract of this Sideritis species also showed a strong anti-inflammatory effect in a croton oil-induced corneal oedema model in rabbits during the chronic stage (45). Later, several novel labdane-type diterpene derivatives were reported as active anti-inflammatory constituents of the n-hexane extract of $S$. javalambrensis. Based on in vitro studies, it has been concluded that these compounds interact with the eicosanoid system, possibly inhibition ofby inhibiting the phospholipase A2 enzyme.

Apart from the flavonoid and diterpene derivatives, the sterol fractions of the Sideritis species were also shown to possess anti-inflammatory and immunomodulating activity. The lipid fraction from S. javalambrensis (44) and a sterol fraction composed of campesterol, stigmasterol and $\beta$-sitosterol from $S$. foetens (8) were also reported as active components. The oral administration of 30 and $60 \mathrm{mg} / \mathrm{kg}$ of the sterol fraction inhibited the oedema formation in the mouse paw between 3 and $7 \mathrm{~h}$ after carrageenan administration. The highest inhibitory effect was obtained after 3 $\mathrm{h}$, with values of $30.1 \%$ for $30 \mathrm{mg} / \mathrm{kg}$ and $37.4 \%$ for $60 \mathrm{mg} /$ $\mathrm{kg}$ of the sterol fraction. In addition, the topical application of $0.25,0.5$ and $1 \mathrm{mg} /$ ear of the sterol fraction reduced the oedema formation induced by TPA in mice with inhibition percentages of 41,43 and $58.7 \%$, respectively, associated with a reduction in the neutrophil infiltration into inflamed tissues.

As anti-inflammatory constituents, the polymethoxyflavone isolated from $S$. tragoriganum, 5-O-demethylnobiletin, may act through the direct inhibition of 5-LOX, without affecting the expression of COX-2. It is known that lipid peroxides promote arachidonic acid metabolism and that a redox agent, such as phenolic derivatives, can inhibit the oxidation of arachidonic acid by 5-lipoxygenases; thus, antioxidant and free radical-scavenging flavonoids could prevent the generation of inflammatory mediators. The anti-inflammatory and antinociceptive activities of $S$. ozturkii extracts were confirmed, and a flavone glycoside, ozturkoside C, was isolated as one of the active ingredients. Despite a high number of studies reporting the antiinflammatory and antinociceptive activities of several Sideritis species, only two flavonoids have been isolated and defined as the active constituents, hypolaetin-8-glucoside and 5-O-demethylnobiletin. Hypolaetin-8-glucoside shows a chemical structure very close to that of ozturkoside $C$, both having luteoline-type flavone glycoside structure (3). Another anti-inflammatory labdane derivative, andalusol, was also isolated from the acetone extract of $S$. foetens, and its activity profile was elucidated (9). Andalusol exerted in vivo anti-inflammatory activity when tested in different inflammation models in mice (carrageenan-induced paw oedema and TPA-induced ear oedema). Oral administration of andalusol inhibited oedema formation, especially the late phase of paw inflammation $(5 \pm 7 \mathrm{~h}$ after carrageenan injection). Andalusol also exerted topical anti-inflammatory activity $4 \mathrm{~h}$ after TPA ear application, inhibiting oedema formation and cell infiltration. This compound affected various leukocyte functions and decreased the histamine release from the mast cells. The activation of macrophages with pro-inflammatory cytokines and bacterial cell wall components promotes the synthesis and release of large amounts of nitric oxide (NO), eicosanoids and bioactive lipids, such as prostaglandins and leukotrienes, mediators involved in the inflammatory onset. Recently, inhibitors of inducible nitric oxide synthase, the isoenzyme responsible for the high-output NO synthesis, have been proposed as anti-inflammatory agents, mainly because the inhibition of exacerbated NO formation may be of therapeutic benefit in these disorders. Moreover, a role of andalusol's effect on the macrophage expression of NOS-2 has been reported in in vivo inflammation models, such as carrageenan-induced hind paw inflammation in the rat. In addition, the action of andalusol on NF-kB activity has been evaluated, but the experiments carried out after simultaneous stimulation with LPS and IFN-g strongly suggested that in addition to NF-kB, it is likely that there is an inhibitory action on the IFN-g signalling. Indeed, this phenomenon has been described for triterpenes, and if it is also the case for andalusol, it opens additional perspectives for the study of the therapeutic action of these molecules (9).

In addition, anti-inflammatory activity studies have been conducted using isolated flavonoids. The study of the anti-inflammatory activity of a series of glycosides/aglycone pairs, through the inhibition of eicosanoid generation via the 5-lipoxygenase and cyclo-oxygenase pathways in elicited rat peritoneal leukocytes stimulated with calcium ionophore, revealed the structural-activity relationship. Among these pairs, hypolaetin-8-glucoside and its corresponding aglycone, hypolaetin, which was isolated from $S$. mugronensis, ,were studied. The results showed that hypolaetin inhibits the 5-lipoxygenase enzyme activity in a more powerful and selective way than hypolaetin-8-glucoside $(\mathrm{IC} 50=4.5 \mu \mathrm{M}, \mathrm{IC} 50=56 \mu \mathrm{M}$, respectively). If we compare these results with others obtained from other pairs, it is confirmed that the sugar moiety reduces the inhibitory potency. In the same study, a structural-activity relationship in flavonoids was found: those flavonoids with a catechol group in the B ring are potent and selective inhibitors of 5-lipoxygenase. However, flavonoids with hydroxyl substituents in their structures, except for the B-ring, are selective against the cyclo-oxygenase enzyme (46).

\section{Antioxidant activity}

In all aerobic organisms, including human beings, the production of reactive oxygen species (ROS) is balanced by an antioxidant defence system. ROS in the forms of superoxide anion, hydroxyl radicals and hydrogen peroxide, which are generated by normal metabolic processes or from exogenous factors and agents, affects DNA, proteins and most biological molecules containing a lipid component of polyunsaturated fatty acids. A serious imbalance between the production of ROS and the antioxidant defence system is responsible for oxidative stress. Thus, ROS play 
an important role in the aetiology of many diseases and of ageing. Antioxidant defence systems that prevent the oxidative damage by ROS consist of flavonoids, carotenoids, phenolic compounds, vitamins and antioxidant enzymes. The role of antioxidants has attracted much interest with regard to their protective effect against free radical damage, which may be the cause of many diseases, including cancer. The results have shown that the antioxidant activities of the extracts do not necessarily correlate with high amounts of phenolics. Although the extracts were found to be effective natural antioxidants, their potential exploitable beneficial effects and their safety in humans need to be proven in clinical trials.

The antioxidant activity was evaluated for methanolic extracts $(0.02 \%$ and $1 \%)$ from twenty-seven Sideritis species by measuring Fe2+-induced linoleic acid peroxidation. The antioxidant activity improved with increasing concentration in every case. Moreover, studying the free radical scavenging activity using the DPPH (1,1-diphenyl-2-picrylhydrazyl) method showed that the higher total phenolic content, the higher the free radical scavenging activity: S. amasiaca and S. germanicopolitana ssp. viridis, with the highest amounts of phenolic derivates, were the most active (47).

The total antioxidant capacity of S. sipylea was determined by the thiocyanite method. The obtained extracts in the linoleic acid emulsion were able to reduce the formation of peroxides. S. sipylea, an endemic species in Turkey, showed radical scavenging antioxidant activities (48). S. syriaca ssp. syriaca, endemic in the mountainous regions of Crete (Greece) and widely used for the preparation of traditional infusions, was proved to possess good antioxidant capacity in its more polar (diethyl ether, ethyl acetate and butanol) extracts. The phytochemical analysis of the extracts revealed the presence of significant quantities of phenylpropanoid acid derivatives and flavonoids (mainly flavones) $(14,49)$, which have been considered responsible for antioxidant activity. The ethyl acetate fraction possessed the highest antioxidant activity, which could be attributed to the presence of phenolic compounds, such as apigenin and isoscutellarein glycosides.

This relation between the antioxidant activity and the phenolic content has also been found for the methanolic extracts from S. ozturkii and S. caesarea, and the results obtained from the DPPH method were $41.68 \pm 1.96 \%$ and $72.47 \pm 0.73 \%$, respectively, at $100 \mathrm{ppm}$ concentration. The higher radical scavenging activity is shown by higher percentage values of inhibition. The total phenolics and total flavonol content were higher for the latter species (50). The present study suggests that the extracts of these plants are a potential source of natural antioxidant agents.

The antioxidant potential was investigated for the entkauranes and the petroleum ether and acetone extracts of the aerial parts of $S$. arguta by three methods, $\beta$-carotene bleaching, free-radical scavenging and superoxide-anion scavenging activity. Both the methanol and the acetone extracts exhibited similar antioxidant activity in every assay. The petroleum ether extract showed antioxidant ability by the $\beta$-carotene bleaching and superoxide-anion methods. However, it did not show any antioxidant ability by the DPPH method. The only active diterpenoid was 7-epicandicandiol.

The methanolic, ethereal, butanolic and aqueous extracts from the aerial parts of S. perfoliata subsp. perfoliata and the isolated flavonoids and phenylpropanoid glycosides from this species were evaluated for their antioxidant properties in different in vitro assays, including scavenging DPPH and TBA (thiobarbituric acid) lipid peroxidation (2).

Moreover, the antioxidant activities of S. javalambrensis and Sideritis libanotica subsp. linearis were reported, with phenylpropanoid glycoside acteoside recognised as a reducing agent able to interact with free radical species (of relevance to the autoxidation mechanism) $(2,19,47)$.

In Greece, Sideritis species have been used as flavouring additives and preservatives in olive oil. Because various flavonoids have been identified in Sideritis species and because it is known that these have high antioxidant activity, it is possible that S. euboea can be used as a source of natural food antioxidants with economic benefits, especially for Greece (51). Despite the traditional use of this plant, in a placebo-controlled clinical trial recently performed to evaluate its antioxidant activity, no significant differences were found in the blood biochemical parameters (glutathione, nitrites, coenzyme Q10 or vitamins C, A and E) between the placebo and the intervention groups.

The antioxidant activity of $S$. raeseri Boiss. et Heldr. subsp. raeseri methanolic extract, evaluated using $\mathrm{Co}(\mathrm{II}) /$ EDTA-induced luminol chemiluminescence and the 2,2diphenyl-1-picrylhydrazyl (DPPH•) free radical assay, was found to be moderate. The activity may be related to the presence of 5- and 8-O-disubstituted flavones. The obtained results were IC50 $1.63 \mathrm{mg}$ mixture/mg DPPH and EC50 $8.3 \mu \mathrm{g} / \mathrm{mL}$, respectively; these activities are moderate when compared with the potent antioxidants quercetin and trolox (26). All the compounds detected in the methanolic subfraction of $S$. raeseri investigated are 7-o( $\beta$-allopyranosyl- $(1 \rightarrow 2)-\beta$-d-glucopyranosyl derivatives of 5,8 -dihydroxyflavones with different substitutions in the B-ring. Four of these compounds are monoacetylated at the C- 6 "' of the allose moiety and one at the C- 6 " of the glucose moiety. An important antioxidant activity would have been expected for these compounds as it was reported that 7,8-dihydroxyflavone showed antioxidant activity similar to that of quercetin, although it lacked any substitution on the B-ring and at the 3-position. In 4,5,8-trihydroxy6,7-dimethoxy flavone, the enhanced antioxidant activity was probably due to the hydroxy and two methoxy groups in ring A. Thus, it is obvious that for flavones with 5,8dihydroxyl substitution in ring A and in some cases with a free hydroxyl group at C4, a more significant antioxidant activity would be expected. Although $p$-hydroxy phenols (ring A) are oxidant systems, a moderate activity has been observed for these compounds. It is probably explained by the fact that in 5,8-dihydroxy flavones, the reducing capacity of the $p$-hydroxy system is suppressed by (1) the intra- 
molecular hydrogen bond between the $\mathrm{OH}$ in $\mathrm{C}-5$ and the carbonyl group and (2) the enhanced inductive effect of the 7-o-glycoside substituent, as opposed to the free hydroxyl group. Furthermore, a systematic comparative study of the antioxidant activity between flavones 5-OH, 7- glycosides and 7-glycosides lacking $\mathrm{OH}$ - substitution on $\mathrm{C}-5$ with or without an $8-\mathrm{OH}$ group is in our future plans.

\section{Anti-ulcerogenic activity}

Plants from the genus Sideritis have also long been used in traditional medicine for their gastroprotective properties. These plants provide a source of natural products with anti-ulcerogenic action, proved in animal tests in vivo and in vitro, including, among other flavonoids, hypolaetin- 8 -glucoside. These flavonoids reduced gastric lesions and drug-induced ulcers in rats by increasing mucus production and decreasing the gastric acidity. According to other studies (52), the presence of a pyrocatechol group at the 3'-4' position in the flavonoid skeleton is related to a higher anti-ulcerative activity.

The aerial parts of S. incana var. virgata, S. funkiana ssp. funkiana, S. funkiana ssp. talaverana and S. hirsuta were prepared as decoctions and orally administered to rats suffering from indomethacin and stress-induced ulcers. This in vivo study of anti-ulcerative activity demonstrated that S. incana var. virgata, S. funkiana ssp. funkiana, and S. funkiana ssp. talaverana were more active against indomethacin-induced ulcers, whereas Sideritis hirsuta was more effective against stress-induced ulcers. S. caesareae was confirmed to possess strong biological activity against ethanol-induced gastric ulceration in rats. Also, studies have been performed on the anti-ulcerogenic activity of hypolaetin-8-O- $\beta$-d-glucoside, a flavonoid isolated from $S$. leucantha and present in several Sideritis species (S. mugronensis, S. angustifolia and S. saetabensis) (52-54).

In addition, a strong dose-dependant activity against Helicobacter pylori was observed for S. italica essential oil, in concentrations between 5 and $25 \mu \mathrm{g} / \mathrm{mL}$ (1).

\section{Analgesic activity}

A $p$-benzoquinone (PBQ)-induced abdominal constriction test was performed on mice for the determination of antinociceptive activity in S. brevibracteata (10). The results are in good accordance with the uses of this genus. Namely, the dried flowering spikes of the Sideritis species are used as herbal tea in the western and southern coastal regions of Turkey due to their pleasant aroma. The n-butanol extract of S. brevibracteata exhibited the highest antinociceptive activity. It was considered that the active compounds for antinociceptive activity could be flavonoids, which are the major components of the n-butanol fraction (3). The anti-nociceptive effects of the ethanol extract, as well as the aqueous and chloroform fractions from S. lotsyi var. mascaensis, have been investigated using the writhing test induced by acetic acid in mice. At $250 \mathrm{mg} / \mathrm{kg}$ p.o., the ethanol extract significantly inhibited the writhing responses at different times and was more active than the other evaluated fractions. The chloroform fraction was more active than the aqueous extract at $125 \mathrm{mg} / \mathrm{kg} \mathrm{p.o} \mathrm{(5).} \mathrm{A}$ dose of $400 \mathrm{mg} / \mathrm{kg}$ p.o. of petroleum ether extract obtained from the flowering aerial parts of S. taurica exhibited an analgesic activity similar to that produced by a doseage of $400 \mathrm{mg} / \mathrm{kg}$ of acetylsalicylic acid (4). The antinociceptive activities of $S$. ozturkii extracts were confirmed, and a flavone glycoside, ozturkoside $C$, was isolated as one of the active ingredients, as already mentioned (3).

\section{Antiproliferative activity}

Demirtas et al. (2009) reported that the methanolic extract from the aerial parts of S. libanotica ssp. linearis showed a significant antiproliferative activity against three human cell lines, Vero cells (African green monkey kidney), C6 cells (rat brain tumour cells) and HeLa cells (human uterus carcinoma) (11).

\section{Anti-HIV activity}

An in vitro study was carried out on H9 lymphocyte cells to determinate the anti-HIV activity of linearol and of twenty-six semisynthetic ent-kaurene derivatives from linearol. The results showed that linearol was inactive (55).

\section{Anticholinesterase activity}

The petroleum ether and acetone extracts of the whole plant of Sideritis congesta P.H. Davis \& Hub.-Mor. and the isolated compounds belonging to ent-kaurane diterpenoids (epoxyisolinearol, sideroxol, sideridiol, siderol, 7-epicandicandiol, linearol and sidol) were evaluated for their anticholinesterase activity, and most of the diterpenes exhibited weak acetylcholinesterase inhibitory activity. However, almost all diterpenes exhibited some inhibitory activity against butyrylcholinesterase; in particular, sideroxol and 7-epicandicandiol exhibited better BChE inhibitory activity than the standard compound galanthamine (56).

\section{Selective oestrogen receptor modulator (SERM) activity}

Traditional therapeutic agents (selective oestrogen receptor modulators or SERMs, biphosphonates, calcitonin) may have serious side effects or contraindications. In an attempt to find food components with the potential to act as SERMs, plant aqueous extracts derived from the Greek flora S. euboea and S. clandestina were submitted in a series of in vitro biological assays reflective of the SERM profile. Their ability (a) to stimulate the differentiation and mineralisation of osteoblastic cell culture by histochemical staining for alkaline phosphatase and Alizarin Red-S staining, (b) to induce, like antioestrogens, the insulin growth factor binding protein 3 (IGFBP3) in MCF-7 breast cancer cells, and (c) to proliferate cervical adenocarcinoma (HeLa) cells were examined using the MTT assay. The data revealed that all the plant extracts studied at a concentration range of $10-100 \mu \mathrm{g} / \mathrm{mL}$ stimulate osteoblastic cell differentiation and exhibit an antioestrogenic effect on breast cancer cells without proliferative effects on cervical adenocarcinoma 
cells. The presence of estradiol inhibited the antioestrogenic effect induced by the extracts in MCF-7 cells, suggesting an oestrogen receptor-related mechanism (13).

\section{Antimicrobial activity}

There are several reports on the antimicrobial activity of Sideritis essential oil. The antimicrobial activity of the essential oils of S. perfoliata and S. trojana was tested against Escherichia coli (NRRL B-3008), methicillin-resistant Staphylococcus aureus (MRSA), Enterobacter aerogenes (NRRL 3567), Salmonella typhimurium (NRRL B-4420), Bacillus cereus (NRRL B-3711), Staphylococcus epidermidis (ATCC 12228) and Candida albicans. The results of the antimicrobial assays indicated that E. coli, methicillinresistant $S$. aureus (MRSA), E. aerogenes, B. cereus, and $C$. albicans were moderately inhibited by the oil of $S$. trojana with MIC values of 125 to $250 \mathrm{mg} / \mathrm{mL}$, which were lower than the MIC values of the standard antimicrobial agent. The oil showed a strong inhibitory effect against $S$. epidermidis with a MIC value of $62.5 \mathrm{mg} / \mathrm{mL}$. Except for C. albicans, S. perfoliata oil, however, was less active (125 to 500 $\mathrm{mg} / \mathrm{mL}$ ) against the test microorganisms. The occurrence of a higher content of oxygenated derivatives of mono and sesquiterpenes (20\%) in the oil of S. trojana may be responsible for the better antimicrobial activity $(35,57)$.

In addition, there are several reports about the antimicrobial activity of essential oil from Spanish Sideritis species. $S$. angustifolia, S. funkiana, S. javalambrensis, S. leucantha, S.

mugronensis and $S$. tragoriganum inhibited the growth of Gram-positive bacteria, Staphylococcus aureus, Mycobacterium phlei and the fungi Candida albicans, whereas they did not show any activity against Gram-negative bacteria. Similar results were obtained in the investigation of the essential oils of S. curvidens and S. lanata, which had no effect against any Gram-negative bacteria, but they showed significant activity against Gram-positive bacteria $(58,59)$.

In contrast, essential oils from S. cilicica and S. bilgerana exerted a significant inhibitory effect against several Gram-negative (Salmonella typhimurium, Escherichia coli) and Gram-positive (Staphylococcus aureus, Bacillus cereus, Staphylococcus epidermidis) bacteria, with a MIC value from 0.125 to $0.5 \mathrm{mg} / \mathrm{mL}$, as well as against Candida albicans (MIC $0.03 \mathrm{mg} / \mathrm{mL}$ ). This antibacterial activity could be due to the presence of $\alpha$-pinene and $\beta$-pinene as the main constituents of both species (60). Also, S. italica essential oil was investigated because of its antimicrobial activity, which has been shown to be higher against Gramnegative than Gram-positive bacteria, especially against Pseudomonas aeruginosa (1).

Not only the essential oils but also the various Sideritis extracts possess significant antibacterial activity. According to the study performed by Sagdic et al. (50), the methanolic extracts of $S$. ozturkii and $S$. caesarea had considerable antimicrobial activity. The fifteen microorganisms used as test organisms were Aeromonas hydrophila ATCC 7965, Bacillus brevis FMC 3, B. cereus FMC 19, B. subtilis ATCC 6630, B. subtilis var. niger ATCC 10, E. coli ATCC 25922,
Klebsiella pneumoniae FMC 5, Morgenella morganii, Mycobacterium smegmatis RUT, Proteus mirabilis BC 3624, Pseudomonas aeruginosa ATCC 27853, Staphylococcus aureus ATCC 28213, Yersinia enterocolitica ATCC 1501, Candida albicans ATCC 1223 and Saccharomyces cerevisiae BC 5461. Linearol, foliol, epicandicandiol and siderol, which are found in the mentioned Sideritis species, were also investigated for antibacterial activities, and epicandicandiol had the highest antimicrobial activity against $E$. coli.

The acetone and methanol extracts of Sideritis tmolea P. H. Davis were tested against standard bacterial strains, such as Escherichia coli, Staphylococcus aureus, Mycobacterium smegmatis, Mycobacterium tuberculosis H37Ra (ATCC 25177) and the yeast Candida albicans. The results of the activity studies showed no significant antimicrobial or antituberculous activity for the Sideritis species' crude acetone and methanol extracts (61).

\section{CONCLUSIONS}

The genus Sideritis provides a wide range of research possibilities. This work is a comprehensive overview of the botanical, phytochemical and pharmacological aspects of the genus Sideritis, objectively presenting the scientific basis of its ethnopharmacological use.

\section{ACKNOWLEDGEMENT}

The authors thank the Serbian Ministry of Education and Science, project III 45017.

\section{REFERENCES:}

1. Basile A, Senatore F, Gargano R, Sorbo S, Del Pezzo M, Lavitola A, Ritieni A, Bruno M, Spatuzzi D, Rigano D, Vuotto ML. Antibacterial and antioxidant activities in Sideritis italica (Miller) Greuter et Burdet essential oils. J Ethnopharmacol 2006; 107: 240-8

2. Charami M, Lazari D, Karioti A, Skaltsa H, Hadjipavlou-Litina D, Souleles C. Antioxidant and Antiinflammatory Activities of Sideritis perfoliata subsp. perfoliata (Lamiaceae). Phytother Res 2008; 22: 450-4

3. Küpeli E, Şahin FP, Çalış I, Yeşilada E, Ezer N. Phenolic compounds of Sideritis ozturkii and their in vivo antiinflammatory and antinociceptive activities. J Ethnopharmacol 2007; 118: 356-60

4. Aboutabl EA, Nassar MI, Elsakhawy FM, Maklad YA, Osman AF, El-Khrisy EAM. Phytochemical and pharmacological studies on Sideritis taurica Stephan ex Wild. J Ethnopharmacol 2002; 82: 177-84

5. Hernàndez-Pérez M, Rabanal RM. Evaluation of the antinflammatory and analgesic activity of Sideritis canariensis var. pannosa in mice. J Ethnopharmacol 2002; 81: 43-7 
6. Bondì ML, Bruno M, Piozzi F, Can Baser KH, Simmonds MSJ. Diversity and antifeedant activity of diterpenes from Turkish species of Sideritis. Biochem Syst Ecol 2000; 28: 299-303

7. Tomas-Barberan FA, Lopez-Gomex C, Villar A, TomasLorente F. Inhibition of lens aldose reductase by Labiate flavonoids. Planta Med 1986; 52: 239-40

8. Navarro A, de Las Heras B, Villar A. Anti-inflammatory and immunomodulating properties of a sterol fraction from $\mathrm{Si}$ deitis foetens Clem Biol Pharm Bull 2001; 24: 470-3

9. de las Heras B, Navarro A, Díaz-Guerra MJ, Bermejo P, Castrillo A, Boscá L, Villar A. Inhibition of NOS-2 expression in macrophages through the inactivation of NF-kB by andalusol. Br J Pharmacol 1999; 28: 605-12

10. Güvenç A, Okada Y, Küpeli Akkol E, Duman H, Okuyama T, Çalıs I. Investigations of anti-inflammatory, antinociceptive, antioxidant and aldose reductase inhibitory activities of phenolic compounds from Sideritis brevibracteata. Food Chem 2010; 118: 686-92

11. Demirtas I, Sahin A, Ayhan B, Tekin S, Telci I. Antiproliferative effects of the methanolic extracts of Sideritis libanotica Labill. subsp. Linearis. Rec Nat Prod 2009; 3: 104-9

12. Ertaş A, Öztürk M, Boga B, Topçu G. Antioxidant and anticholinesterase activity evaluation of ent-kaurane diterpenoids from Sideritis arguta. J Nat Prod 2009; 72: 500-2

13. Kassi E, Papoutsi Z, Fokialakis N, Messari J, Mitakou S, Moutsatsou P. Greek plant extracts exhibit selective estrogen receptor modulator (SERM)-like properties. J Agric Food Chem 2004; 52: 6956-61

14. Plioukas M, Termentzi A, Gabrieli C, Zervou M, Kefalas P, Kokkalou E. Novel acylflavones from Sideritis syriaca ssp. syriaca. Food Chem 2010; 123: 1136-41

15. Petreska J, Stefova M, Ferreres F, Moreno DA, ThomasBarberan FA, Stefkov G, Kulevanova S, Gil-Izquiredo A. Potential bioactive phenolics of Macedonian Sideritis species used for medicinal "Mountain tea". Food Chem 2011; 125: 13-20

16. Tomas-Barberan FA, Rejdali M, Harborne JB, Heywood V. External and vcuolar flavonoids from ibero-North African Sideritis species. A chemosystematic approach. Phytochemistry 1988; 27: 165-70

17. Alipieva KI, Kostadinova EP, Evstatieva LjN, Stefova M, Bankova VS. An iridoid and a flavonoid from Sideritis lanata L. Fitoterapia 2009; 80: 51-3

18. Kilic T. Isolation and biological activity of new and known diterpenoids from Sideritis stricta Boiss. \& Heldr. Molecules 2006; 11: 257-62

19. Rios JL, Manez S, Paya M, Alcaraz MJ. Antioxidant activity of flavonoids from Sideritis javalabrensis. Phytochemistry 1992; 31: 1047-50

20. Palá-Paúl J, Pérez-Alonso MJ, Velasco-Negueruela A, Ballesteros MT, Sanz J. Essential oil composition of Sideritis hirsuta L. from Guadalajara Province, Spain. Flavour Frag J 2006; 21: 410-5

21. Diklić N. Genus Sideritis L. In: Flora of Serbia. Josifović M, editor. Serbian academy of Sciecne and Art; 1974. Vol. IV: p. 371-2
22. Koleva I, Linssen JPH, van Beek TA, Evstatieva LN, Kortenska V, Handjieva N. Antioxidant activity screening of extracts from Sideritis species (Labiatae) grown in Bulgaria . J Sci Food Agric 2003; 83: 809-19

23. Đorđević S, Blagojević S, Sekulović D, Sekešan V, RunjaićAntić D. The analysis of mineral content in active components and the preparation of phytopreparations for anemia prevention. Arh Pharm 1993; 43: 225-31

24. Barber JC, Ortega JF, Santos-Guerra A, Marrero A, Jansen RK. Taxonomists evolution of endemic Sideritis (Lamiaceae) in Macaronesia: Insights from a chloroplast DNA restriction site analysis. Syst Bot 2000; 25: 633-47

25. Fraga BM, Hernández MG, Fernández C, Santana JMH. A chemotaxonomic study of nine Canarian Sideritis species. Phytochemistry 2009; 70: 1038-48

26. Gabrieli CN, Kefalas PG, Kokkalou EL. Antioxidant activity of flavonoids from Sideritis raeseri. J Ethnopharmacol 2005; 96: 423-8

27. Janeska B, Stefova M, Alipieva K. Assay of flavonoid aglycones from the species of genus Sideritis (Lamiaceae) from Macedonia with HPLC-UV DAD. Acta Pharm. 2007; 57: 371-7

28. Kargioglu M, Cenkci S, Serteser A, Evliyaoglu N, Konuk M, Samil Kök M, Bagci Y. An ethnobotanical survey of Inner-West Anatolia, Turkey. Human Ecol 2008; 36: 763-77

29. Çelik S, Karabacak E, Uysal I. Plants have been collected from mythological Kazdagi (Mt. Ida) National Park, West Turkey by turkmens and their folk, cultural and social uses. Eur J Scien Res 2008; 19: 835-43

30. Ivancheva S, Stantcheva B. Ethnobotanical inventory of medicinal plants in Bulgaria. J Ethnopharmacol 2000; 69: 165-72

31. Sahin FP, Ezer N, Calis I, Terpenic and Phenolic Compounds from Sideritis stricta, Turk J Chem 2006; 30: $495-504$

32. Logoglu E, Arslan S, Öktemer A, Takıyan I. Biological Activities of Some Natural Comp ounds from Sideritis sipylea Boiss. Phytother Res 2006; 20: 294-7

33. Gomez-Serranillos, Carretero E, Slowing K, Palomino OM, Villarrubia AI, Villar A. HPLC Quantitative Analysis of Diterpenoids in Sideritis (Labiatae) Species. Phytother Res 1998; 12: S101-S103

34. Palomino OM, Gomez-Serranillos P, Carretero E, Villar A. High-performance liquid chromatography of flavonoids from Sideritis species. J Chromatog A 1996; 731: 103-8.

35. Kirimer N, Baser KHC, Demirci B, Duman H. Essential oils of Sideritis species of Turkey belonging to the section Empedoclia. Chem Nat Compd 2004; 40: 19-23

36. Ezer N, Vila R, Caiqigueraland S, Adzet T. Essential oil composition of four Turkish species of Sideritis. Phytochemistry 1996; 41: 203-5.

37. Baser KHC. Aromatic biodiversity among the flowering plant taxa of Turkey. Pure App Chem 2002; 74: 527-45 
38. Aligiannis N, Kalpoutzakis I, Chinou B, Mitakou S. Composition and antimicrobial activity of the essential oils of five taxa of Sideritis from Greece. J Agricul Food Chem 2001; 49: 811-15

39. Ertan A, Azcan N, Demirci B, Baser KHC. Fatty acid composition of Sideritis species. Chem Nat Comp 2001; 37: 301-3

40. Ezer N, Sakar MK, Rodríguez B, De la Torre MC. Flavonoid glycosides and a phenylpropanoid glycoside from Sideritis perfoliata. Internat J Pharmacognosy 1992; 30: 61-5

41. Pinar S, Ezer N, Çalis I. Three acylated flavone glycosides from Sideritis ozturkii Aytac \& Aksoy. Phytochemistry 2004; 65: 2095-99

42. Rodríguez-Lyon M, Díaz-Lanza AM, Bernabé M, Villaescusa-Castillo L. Flavone glycosides containing acetylated sugars from Sideritis hyssopifolia. Magn Reson Chem 2000; 38: 684-7

43. Hernández-Pérez M, Sánchez-Mateo CC, MontalbettiMoreno Y, Rabanal RM. Studies on the analgesic and anti-inflammatory effects of Sideritis candicans Ait. var. eriocephala Webb aerial part. J Ethnopharmacol 2004; 93: 279-84

44. Godoy A, de las Heras B, Vivas JM, Villar A. Anti-inflammatory properties of a lipid fraction obtained from Sideritis javalambrensis. Biol Pharm Bull 2000; 23: 1193-97

45. Villena C, Vivas JM, Villar AM. Suppression of croton oil-induced rabbit corneal edema by Sideritis javalambrensis. J Ethnopharmacol 2000; 71: 301-5

46. Moroney MA, Alcaraz MJ, Forder RA, Carey F, Hoult RS. Selectivity of neutrophil 5-lypoxygenase and cyclooxygenase inhibition by an anti-inflammatory flavonoid glycoside and related aglycone flavonoids. J Pharm Pharmacol 1988; 40: 787-92

47. Tunalier Z, Kosar M, Ozturk N, Baser KHC, Duman $\mathrm{H}$, Kirimer N. Antioxidant properties and phenolic composition of Sideritis species. Chem Nat Comp 2004; 40: 206-10

48. Nakiboglu M, Ozturk Urek R, Kayali HA, Tarhan L. Antioxidant capacities of endemic Sideritis sipylea and Origanum sipyleum from Turkey. Food Chem 2007; 104: 630-5

49. Armata M, Gabrieli C, Termentzi A, Zervou M, Kokkalou E. Constituents of Sideritis syriaca. ssp. syriaca (Lamiaceae) and their antioxidant activity. Food Chem 2008; 111: 179-86

50. Sagdic O, Aksoy A, Ozkan G, Ekici L, Albayrak S. Biological activities of the extracts of two endemic Sideritis species in Turkey. Innov Food Sci Emerg Technol 2008; 9: $80-4$

51. Tsaknis J, Lalas S, Extraction and identification of natural antioxidant from Sideritis euboea (Mountain Tea). J Agric Food Chem 2005; 53: 6375-81

52. Alcaraz MJ, Tordera M. Studies on the gastric antiulcer activity of hypolaetin-8-glucoside. Phytother Res 1988; 2 : 85-8

53. Zarzuelo A, Garcia E, Jiménez J, Ocete MA, Utrilla P, Socorro O. Antiinflammatory and anti-ulcerative activity of various species of the genus Sideritis from the Alpujarra region of Spain. Fitoterapia 1993; 64: 26-30

54. Gürbüz I, Özkan AM, Yesilada E, Kutsal O. Anti-ulcerogenic activity of some plants used in folk medicine of Pinarbasi (Kayseri, Turkey). J Ethnopharmacol 2005; 101: 313-8

55. Bruno M, Rosselli S, Pibiri I, Kilgore N, Lee K-H. AntiVIH agents derived from the ent-kaurene diterpenoid linearol. J Nat Prod 2002; 65: 1594-7

56. Topçua G, Ertas A, Öztürk M, Dinçel D, Kılıc T, Halfon B. Ent-kaurane diterpenoids isolated from Sideritis congesta. Phytochem Lett 2011 doi: 10.1016/j. phytol.2011.05.001

57. Kirimer N, Demirci B, Iscan G, Baser KHC, Duman H. Composition of the essential oils of two Sideritis species from Turkey and antimicrobial activity. Chem Nat Comp 2008; 44: 121-3

58. Ügur A, Varol O, Ceylan O. Antibacterial activity of Sideritis curvidens and Sideritis lanata from Turkey. Pharmaceut Biol 2005; 43: 47-52

59. Villar A, Recio MC, Ríos JL, Zafra-Polo MC. Antimicrobial activity of essential oils from Sideritis species. Pharmazie 1986; 41: 298-99

60. Iscan G, Kirimer N, Kurkcuoglu M, Baser KHC. Composition and antimicrobial activity of the essential oils of two endemic species from Turkey: Sideritis cilicica and Sideritis bilgerana. Chem Nat Comp 2005; 41: 679-82

61. Çarıkç S, Çöl Ç, Kılıç T, Azizoglu A. Diterpenoids from Sideritis tmolea P. H. Davis. Rec Nat Prod 2007; 4:44-50. 